\title{
Dementia, Stroke and Parkinson's Disease in Spanish Populations: A Review of Door-to-Door Prevalence Surveys
}

\author{
José Luis del Barrio ${ }^{a}$ Jesús de Pedro-Cuesta ${ }^{a}$ Raquel Boix ${ }^{a}$ Jesús Acosta \\ Alberto Bergareche $^{f}$ Félix Bermejo-Pareja ${ }^{b}$ Rafael Gabriel ${ }^{c}$ \\ María Jesús García de Yébenes ${ }^{d}$ Francisco José Garcíag Secundino López-Pousah \\ José María Manubens ${ }^{i}$ Raimundo Mateos jordi Matías-Guiuk Josep María Olivé

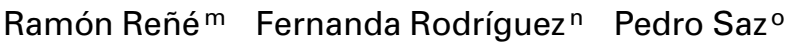 \\ aCentro Nacional de Epidemiología, Instituto de Salud Carlos III, bServicio de Neurología, Hospital Universitario \\ 12 de octubre, ' Unidad de Epidemiología Clínica-Investigación, Hospital Universitario de la Princesa, y \\ dProyecto 'Envejecer en Leganés', Técnicas Avanzadas de Investigación en Salud, Madrid, e Unidad de Neurología,

 \\ gUnidad de Geriatría, Hospital Geriátrico Virgen del Valle, Toledo, hUnidad de Demencias, Hospital Santa Caterina, \\ Gerona, 'Unidad de Neurología, Hospital Virgen del Camino, Pamplona, 'Unidad de Psicogeriatría, \\ Hospital Psiquiátrico de Conxo, Santiago de Compostela, ${ }^{k}$ Unidad de Neurología, Hospital General Universitario \\ de Alicante, Alicante, 'Hospital de Sant Joan, Reus, mUnidad de Diagnóstico y Tratamiento de las Demencias, \\ Servicio de Neurología, Hospital Universitario de Bellvitge, Barcelona, nUnidad de Neurología, Hospital General de \\ Segovia, Segovia, y ${ }^{\circ}$ Departamento de Medicina y Psiquiatría, Universidad de Zaragoza, Zaragoza, España
}

\section{Key Words \\ Dementia · Alzheimer's disease $\cdot$ Stroke $\cdot$ Parkinson's disease $\cdot$ Prevalence $\cdot$ Epidemiology, aged population}

\begin{abstract}
We identified 14 door-to-door prevalence surveys on dementia, parkinsonism or stroke in Spanish populations fulfilling specific criteria and combined selected age- and sex-specific data using logistic regression and taking Pamplona as a reference. The prevalence of dementia and of Alzheimer's disease varied significantly with space. However, the largest variation was seen for vascular dementia: odds ratio (OR) and $95 \%$ confidence interval (Cl) for Gerona were 6.42 (3.23-12.3) in women and 2.30 (1.10-4.79) in men. Stroke was particularly frequent among Arevalo's women, with OR 2.10 and $95 \% \mathrm{Cl}$ 1.26-3.49. The prevalence of Parkinson's disease was twofold higher in Cantalejo. Although differences in
\end{abstract}

\section{KARGER}

Fax +41613061234

E-Mail karger@karger.ch www.karger.com
(C) 2005 S. Karger AG, Basel

0251-5350/05/0244-0179\$22.00/0

Accessible online at:

www. karger.com/ned methodology make the interpretation of results problematic, the prevalence of stroke and vascular dementia in Spain seems to vary spatially, indicating a space for prevention.

\section{Introduction}

Data on the incidence and prevalence of dementia, Parkinson's disease (PD) and stroke in Spanish populations are sparse. Furthermore, comparability is low due to differences in survey methodology. Data from populations resident in Pamplona, Gerona and Zaragoza [1-3] have been analyzed by EUROPARKINSON and EURODEM groups funded by the EU BIOMED research program and, at a national level, by the Elderly Neurological Disease Research Group (Grupo de Investigación de Enfermedades Neurológicas en los Ancianos) [4-6]. Al-
Copyright $@ 2005$ S. Karger AG, Basel

José Luis del Barrio Fernández, PhD

Centro Nacional de Epidemiología, Instituto de Salud Carlos III

C/Sinesio Delgado ${ }^{\circ} 6$, Pabellón 12

ES-28029 Madrid (Spain)

Tel. +34 9182226 48, Fax +34 9138778 15, E-Mail jlbarrio@isciii.es 
Fig. 1. Geographic location of surveys.

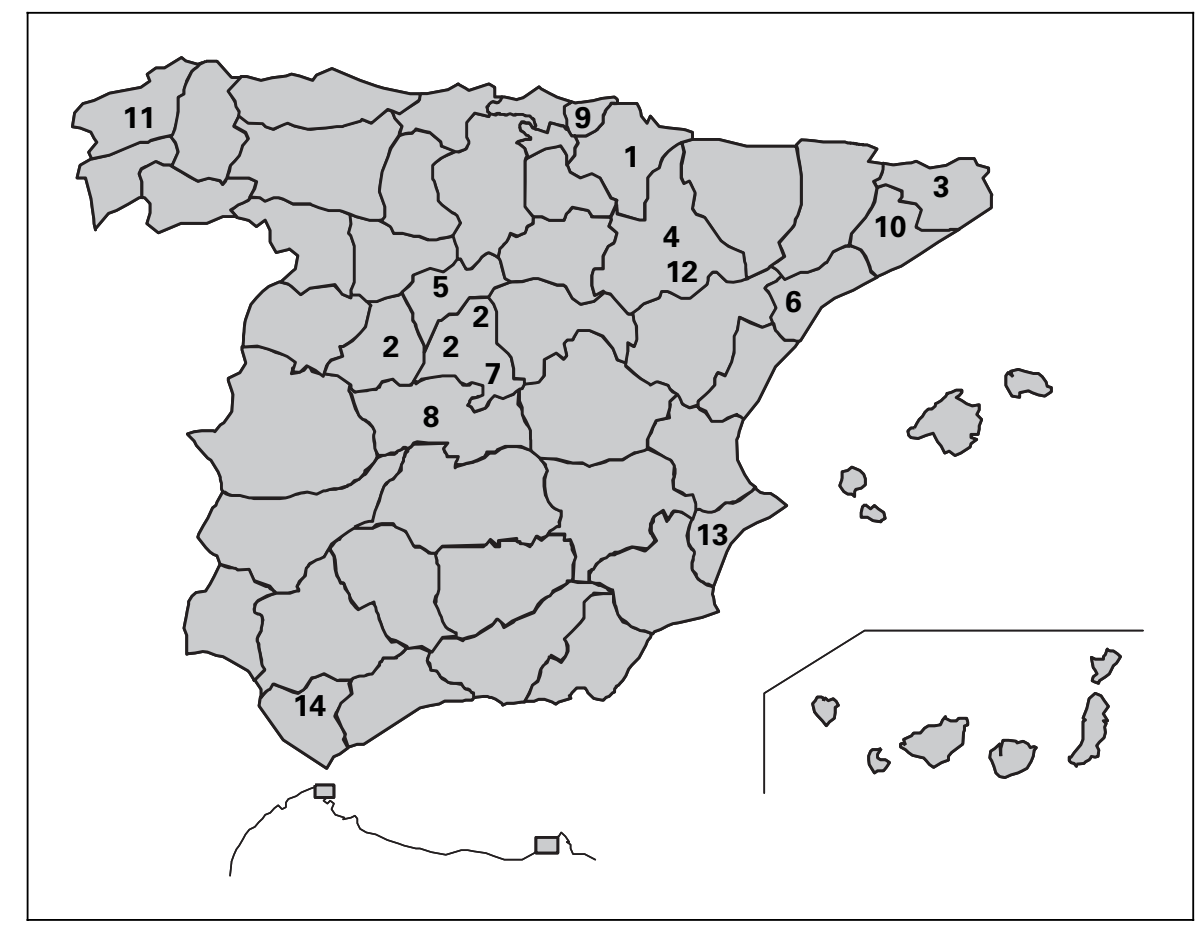
Numbers from table 1.

though such pioneering studies have furnished data of high quality, they currently constitute only a part of the reported Spanish surveys focusing on similar entities [7$15]$.

The aim of this study was to compare reported data on the prevalence of dementia, PD, ischemic stroke and the most important etiological subgroups such as Alzheimer's disease (AD) and vascular dementia (VD). It is well known that prevalence counts for frequent, chronic neurological ailments, generated from diagnoses made in the course of clinical services and registered at community or hospital clinics, constitute underestimates due to the large proportion of undiagnosed individuals affected by such diseases. This undiagnosed proportion is identified, at least in part, in so-called door-to-door surveys, where screening instruments are used in order to detect symptoms, signs or limitations frequently seen in the course of such disorders. For instance, in a recent review of international door-to-door studies of parkinsonism, the proportion of cases diagnosed during the study ranged from 24 to $50 \%$ [7]. Accordingly, this review focused on reported door-to-door studies conducted on Spanish populations.

\section{Methods}

From a Medline search and personal contacts with authors, we identified reports on screening surveys targeting the prevalence of dementia, parkinsonism and stroke. Requirements for classification as screening surveys were explicit mention of: (1) use of an updated population census for a study population geographically defined by residence; (2) use of a screening instrument in the first phase of the study; (3) a description of the clinical procedure and medical specialist responsible for phase II diagnostic ascertainment; (4) a clear classification in diagnostic categories for assignment of a specific prevalence numerator.

Shown in figure 1 and table 1 are geographic/demographic data and the number of cases reported from different studies. There was a lack of surveys covering populations residing in the southern half of the country. Fourteen surveys were identified, focusing on 18 sometimes geographically overlapping - study populations and different combinations of the above-mentioned pathologies. For example, the NEDICES/EPICARDIAN study covered populations resident in: Lista, a centrally situated Madrid city district; Margaritas, a suburb in the town of Getafe, located on the outskirts of Madrid, and Arévalo, a village in the Province of Ávila. Six of the study populations were urban (Zaragoza, ZARADEMP, Leganés, Pamplona, El Prat de Llobregat and Santiago de Compostela), 3 semi-rural (Alcoi/ Bañeres, Cantalejo and La Selva del Camp), 2 rural (Gerona and Vejer de la Frontera) and 3 mixed, sometimes including rural and urban populations in the same denominator (Toledo, NEDICES/ EPICARDIAN, Bidasoa). Eight of the surveys reported prevalence counts for different illnesses in populations ranging from 516 to 3,600 individuals. While some studies focused on only one major entity, such as dementia (Toledo) or parkinsonism (Cantalejo), oth- 
Table 1. Door-to-door prevalence surveys of dementia, stroke or parkinsonism

\begin{tabular}{|c|c|c|c|c|c|c|c|}
\hline Study & Main researchers & $\begin{array}{l}\text { Study population's } \\
\text { place of residence }\end{array}$ & $\begin{array}{l}\text { Age } \\
\text { years }\end{array}$ & $\begin{array}{l}\text { Number of } \\
\text { individuals } \\
\text { studied }\end{array}$ & $\begin{array}{l}\text { Main target } \\
\text { of study }\end{array}$ & $\begin{array}{l}\text { Preva- } \\
\text { lence } \\
\text { year }\end{array}$ & Number of cases \\
\hline (1) Pamplona & J.M. Manubens & $\begin{array}{l}\text { Pamplona } \\
\text { (Navarre) }\end{array}$ & $>70$ & 1,127 & $\begin{array}{l}\text { Dementia } \\
\text { Parkinsonism }\end{array}$ & 1991 & 199 dementia \\
\hline $\begin{array}{l}\text { (2) NEDICES/ } \\
\text { EPICARDIAN }\end{array}$ & $\begin{array}{l}\text { F. Bermejo } \\
\text { R. Gabriel }\end{array}$ & $\begin{array}{l}\text { Margaritas } \\
\text { (Getafe-Madrid) } \\
\text { Lista (Madrid) } \\
\text { Arévalo (Ávila) }\end{array}$ & $>64$ & 5,166 & $\begin{array}{l}\text { Dementia } \\
\text { Stroke } \\
\text { Parkinsonism } \\
\text { Vascular risk factors }\end{array}$ & 1994 & $\begin{array}{l}29 \text { stroke, } 7 \text { transient } \\
\text { ischemic attack } \\
179 \text { parkinsonism } \\
280 \text { dementia }\end{array}$ \\
\hline (3) Gerona & S. López-Pousa & Gerona & $>64$ & 1,414 & $\begin{array}{l}\text { Dementia } \\
\text { Stroke } \\
\text { Parkinsonism }\end{array}$ & 1990 & $\begin{array}{l}186 \text { dementia } \\
44 \text { parkinsonism }\end{array}$ \\
\hline (4) Zaragoza & A. Lobo & Zaragoza & $>64$ & 1,080 & $\begin{array}{l}\text { Dementia } \\
\text { Depression }\end{array}$ & 1992 & 59 dementia \\
\hline (5) Cantalejo & L.E. Clavería & $\begin{array}{l}\text { Cantalejo } \\
\text { (Segovia) }\end{array}$ & $>59$ & 939 & $\begin{array}{l}\text { Parkinsonism } \\
\text { Epilepsy }\end{array}$ & 1994 & 27 parkinsonism \\
\hline (6) La Selva del Camp & J. Pi & $\begin{array}{l}\text { La Selva del Camp } \\
\text { (Tarragona) }\end{array}$ & $>64$ & 516 & Dementia & 1992 & 64 dementia \\
\hline (7) Leganés & Á. Otero & $\begin{array}{l}\text { Leganés } \\
\text { (Madrid) }\end{array}$ & $>70$ & 527 & Dementia & 1999 & 63 dementia \\
\hline (8) Toledo & F.J. García & Toledo & $>64$ & 3,214 & Dementia & 1994 & 94 dementia \\
\hline (9) Bidasoa & A. Bergareche & $\begin{array}{l}\text { Hondarribia } \\
\text { (Guipúzcoa) }\end{array}$ & $>65$ & 2,000 & $\begin{array}{l}\text { Tremor } \\
\text { Parkinsonism } \\
\text { Dementia } \\
\text { Epilepsy } \\
\text { Vascular pathology }\end{array}$ & 1996 & $\begin{array}{l}36 \text { parkinsonism } \\
96 \text { essential } \\
\text { tremor }\end{array}$ \\
\hline (10) El Prat de Llobregat & R. Reñé & $\begin{array}{l}\text { El Prat de Llobregat } \\
\text { (Barcelona) }\end{array}$ & $>70$ & 1,754 & $\begin{array}{l}\text { Dementia } \\
\text { Nutritional status }\end{array}$ & 2002 & (Ongoing) \\
\hline $\begin{array}{l}\text { (11) Santiago de } \\
\text { Compostela }\end{array}$ & R. Mateos & $\begin{array}{l}\text { Santiago de Compostela } \\
\text { (La Coruña) }\end{array}$ & $>64$ & 800 & Cognitive disorders & 2000 & $\begin{array}{l}\text { Cognitive decline } \\
\text { Psychiatric disorders } \\
\text { (Ongoing) }\end{array}$ \\
\hline (12) ZARADEMP & A. Lobo & Zaragoza & $>54$ & 4,803 & $\begin{array}{l}\text { Dementia } \\
\text { Depression } \\
\text { Stroke } \\
\text { Parkinsonism }\end{array}$ & 2000 & $\begin{array}{l}283 \text { dementia } \\
54 \mathrm{PD}\end{array}$ \\
\hline (13) Alcoi/Bañeres & J. Matías-Guiu & $\begin{array}{l}\text { Muro, Bañeres, Alcoi } \\
\text { (Alicante) }\end{array}$ & $>60$ & 3,500 & $\begin{array}{l}\text { Migraine } \\
\text { Stroke } \\
\text { Dementia } \\
\text { Parkinsonism } \\
\text { Others }\end{array}$ & 1993 & 96 migraine \\
\hline (14) Vejer de la Frontera & J. Acosta Varo & $\begin{array}{l}\text { Vejer de la Frontera } \\
\text { (Cadiz) }\end{array}$ & $>60$ & 768 & $\begin{array}{l}\text { Movement disorders } \\
\text { Hypertension } \\
\text { Epilepsy }\end{array}$ & 1988 & $\begin{array}{l}66 \text { movement } \\
\text { disorders } \\
75 \text { epilepsy }\end{array}$ \\
\hline
\end{tabular}

ers covered several disorders. For instance, the NEDICES/EPICARDIAN studies included dementia, parkinsonism and stroke as well as other diagnoses such as essential tremor. The study populations were settled in 10 of 17 autonomous regions, yet the reported results nevertheless corresponded to only 6 , encompassing 23,105 individuals over the age of 59 years as denominator.

The following 11 studies addressed dementia: Zaragoza, ZARADEMP [3, 5]; Leganés [8]; Gerona, NEDICES/EPICARDIAN [2]; Alcoi/Bañeres; Pamplona [1]; El Prat de Llobregat; Toledo
[9]; Santiago de Compostela and La Selva del Camp [10]. One study, ZARADEMP [5], was excluded from the review, since neither denominators nor age- and sex-specific data were available. Four studies, NEDICES/EPICARDIAN, Alcoi/Bañeres, El Prat de LLobregat and Santiago de Compostela, had collected data but not yet reported results on dementia. Therefore they were excluded from the analysis. Seven surveys focused on parkinsonism, i.e. NEDICES/ EPICARDIAN [11], Gerona [4], Alcoi/Bañeres, Pamplona [1], Bidasoa, Cantalejo [7] and ZARADEMP [16], and 5 on stroke, i.e. 
Table 2. Methodological aspects of the screening phase

\begin{tabular}{|c|c|c|c|c|}
\hline Study & Screening instrument & Participation & Application & Field workers \\
\hline (1) Pamplona & $\begin{array}{l}\text { Dementia: CAMCOG (modified Spanish version; } \\
\text { joint administration to patient and carer); cutoff: } \\
\text { <74 score } \\
\text { Parkinsonism: questions about previous diagnosis, } \\
\text { use of antiparkinsonian drugs; neurological } \\
\text { examination: tremor, gait disturbances, clinical } \\
\text { impressions }\end{array}$ & $\begin{array}{l}\text { CAMCOG: } 90.4 \% \\
\text { Parkinsonism: } 82 \%\end{array}$ & $\begin{array}{l}\text { Dementia: individual } \\
\text { direct } \\
\text { Parkinsonism: not } \\
\text { specified }\end{array}$ & $\begin{array}{l}\text { Dementia: } 3 \text { trained } \\
\text { physicians } \\
\text { Parkinsonism: physicians }\end{array}$ \\
\hline $\begin{array}{l}\text { (2) NEDICES } \\
\text { EPICARDIAN }\end{array}$ & $\begin{array}{l}\text { Parkinsonism: Spanish ILSA-adapted version [33] } \\
\text { Stroke: Monica Project items [42] and O’Mahony } \\
\text { et al. [43] }\end{array}$ & $\begin{array}{l}\text { ILSA-adapted version: } \\
89.2 \% \\
\text { Monica Project items: } \\
85.6 \% \text { (urban area), } \\
98.1 \% \text { (rural area) }\end{array}$ & $\begin{array}{l}\text { Parkinsonism: } \\
\text { individual direct, } \\
\text { telephone or mail } \\
\text { Stroke: individual } \\
\text { direct }\end{array}$ & $\begin{array}{l}\text { Parkinsonism: medically } \\
\text { uneducated interviewers } \\
\text { Stroke: general practitioners } \\
\text { or nurses }\end{array}$ \\
\hline (3) Gerona & $\begin{array}{l}\text { Dementia: MEC, Spanish version of the MMSE; } \\
\text { cutoff: } 23 / 24 \\
\text { Parkinsonism: questions on tremor, previous } \\
\text { diagnosis, antiparkinsonian drugs; neurological } \\
\text { examination: tremor, rigidity and bradykinesia } \\
\text { Stroke: screening instrument of the Monica Project } \\
\text { [42], identification of stroke defined by the WHO }\end{array}$ & $\begin{array}{l}\text { MEC: } 92.4 \% \\
\text { Parkinsonism: } 84 \% \\
\text { Monica Project: } 86.3 \%\end{array}$ & $\begin{array}{l}\text { Dementia: individual } \\
\text { direct } \\
\text { Parkinsonism: not } \\
\text { specified } \\
\text { Stroke: individual } \\
\text { direct }\end{array}$ & $\begin{array}{l}\text { Dementia: } 18 \text { previously } \\
\text { trained general practitioners } \\
\text { and nurses } \\
\text { Parkinsonism: physicians } \\
\text { Stroke: general practitioners }\end{array}$ \\
\hline (4) Zaragoza & $\begin{array}{l}\text { Dementia: MEC, Spanish version of the MMSE; } \\
\text { cutoff: } 23 / 24 \\
\text { GMS [44] (Spanish version); AGECAT [45] }\end{array}$ & MEC: $95.2 \%$ & $\begin{array}{l}\text { Dementia: individual } \\
\text { direct }\end{array}$ & $\begin{array}{l}\text { Dementia: } 10 \text { trained } \\
\text { medical students }\end{array}$ \\
\hline (5) Cantalejo & $\begin{array}{l}\text { Parkinsonism: validated method of } 9 \text { questions } \\
\text { [30] }\end{array}$ & Parkinsonism: $78 \%$ & $\begin{array}{l}\text { Parkinsonism: } \\
\text { individual direct, } \\
\text { relatives }\end{array}$ & $\begin{array}{l}\text { Parkinsonism: local expert } \\
\text { field worker }\end{array}$ \\
\hline $\begin{array}{l}\text { (6) La Selva del } \\
\text { Camp }\end{array}$ & $\begin{array}{l}\text { Dementia: MMSE of Folstein et al. [20]; cutoff: } \\
23 / 24\end{array}$ & MMSE: $85.3 \%$ & $\begin{array}{l}\text { Dementia: individual } \\
\text { direct, relative, career }\end{array}$ & Dementia: not specified \\
\hline (7) Leganés & $\begin{array}{l}\text { Dementia: MMSE of Folstein et al. [20], SPMSQ } \\
\text { [46], 7-min test [47], test of informant question- } \\
\text { naire [48], bell test, immediate and long-term recall } \\
\text { from a short story, apprenticeship of } 6 \text { simple } \\
\text { figures, trail-making test form A and subtest of } \\
\text { similarities from the WAIS }\end{array}$ & $\begin{array}{l}\text { No screening phase; } \\
\text { neurological } \\
\text { examination in } 1999 \text { of } \\
\text { survivors of the } 1993 \\
\text { prevalence-study } \\
\text { population }\end{array}$ & $\begin{array}{l}\text { Dementia: individual } \\
\text { direct, career, } \\
\text { telephone }\end{array}$ & $\begin{array}{l}\text { Dementia: } 1 \text { neurologist and } \\
1 \text { neuropsychologist }\end{array}$ \\
\hline (8) Toledo & $\begin{array}{l}\text { Dementia: Spanish version of the MMSE from } \\
\text { Folstein et al. [20]; cutoff: } 17 / 18 \text { for illiterates, } \\
\text { 20/21 for those with less than primary school and } \\
23 / 24 \text { for those with primary school education }\end{array}$ & MMSE: $81.7 \%$ & $\begin{array}{l}\text { Dementia: individual } \\
\text { direct }\end{array}$ & $\begin{array}{l}\text { Dementia: } 17 \text { trained } \\
\text { psychologists }\end{array}$ \\
\hline
\end{tabular}

CAMCOG = Cambridge Cognitive Examination; ILSA = Italian Longitudinal Study on Aging; MEC = Mini Examen Cognitivo; MMSE = Mini Mental State Examination; GMS = Geriatric Mental State Schedule; AGECAT = Automated Geriatric Examination for Computer-Assisted Taxonomy; SPMSQ = Short Portable Mental State Questionnaire; WAIS = Wechsler Adult Intelligence Score.

NEDICES/EPICARDIAN [12-14], Gerona [15], Pamplona [6], Zaragoza [3] and Alcoi/Bañeres. Reports from studies in Vejer de la Frontera (Cadiz) [17] and Alcoi/Bañeres (Alicante) [unpubl. report], focusing on methods where prevalence data were not available, were not included in the methods review. Ongoing surveys in El Prat de Llobregat (Barcelona) and Santiago de Compostela (Coruña), the results of which were either unpublished or in press, such as those from a survey in a Basque population (the Bidasoa study), were excluded from the analysis. Results on prevalence of PD from ZARADEMP, based on self-reported diagnoses, were likewise excluded [16]. Some studies generated prevalence data for other neurological diseases, e.g. transient ischemic attack in Alcoi/Bañeres [18] and essential tremor in Bidasoa [19].
The review of methods focused attention on: type of screening instrument used; type of application, whether direct (individual, or based on a family or institutional informant) or indirect (mail or telephone interview); interviewer or field worker; collaboration level. With regard to methods in phase II, the review emphasized the qualification of the specialist in charge of diagnosis ascertainment and application of diagnostic criteria, and the use of diagnostic protocols and specialist panels for difficult cases. Results were obtained from reported figures in the form of digits or graphs.

Methods in phase I are summarily described in table 2. Instruments purpose-designed to detect specific entities or health status were used in 4 studies, namely cognitive deterioration in Zaragoza, Toledo and La Selva del Camp, and parkinsonism in Cantalejo. Explicit men- 
Table 3. Methodological aspects of diagnostic ascertainment phase

\begin{tabular}{|c|c|c|c|}
\hline Study & Staff & $\begin{array}{l}\text { Participation among } \\
\text { screened positive subjects }\end{array}$ & Diagnostic criteria \\
\hline (1) Pamplona & $\begin{array}{l}\text { Dementia: } 7 \text { neurologists using } \\
\text { a standardized protocol } \\
\text { Parkinsonism: neurologist }\end{array}$ & $\begin{array}{l}\text { CAMCOG+: } 100 \% \\
\text { Parkinsonism: } \\
\text { not specified }\end{array}$ & $\begin{array}{l}\text { Dementia: CAMDEX for dementia } \\
\text { NINCDS-ADRDA for Alzheimer's disease } \\
\text { Hachinski ischemic score for vascular and mixed dementia } \\
\text { Parkinsonism: } 2 \text { of } 4 \text { cardinal signs, i.e. resting tremor, rigidity, } \\
\text { bradykinesia and impaired postural reflexes }\end{array}$ \\
\hline $\begin{array}{l}\text { (2) NEDICES/ } \\
\text { EPICARDIAN }\end{array}$ & Parkinsonism: neurologist & Parkinsonism: 97.9\% & $\begin{array}{l}\text { Parkinsonism: } 2 \text { of } 4 \text { cardinal signs, i.e. resting tremor, rigidity, } \\
\text { bradykinesia and impaired postural reflexes and } 4 \text { other sets }\end{array}$ \\
\hline (3) Gerona & $\begin{array}{l}\text { Dementia: clinical psychologist } \\
\text { and neurologist } \\
\text { Parkinsonism: neurologists }\end{array}$ & $\begin{array}{l}\text { MEC+: } 89.45 \% \\
\text { Parkinsonism: not } \\
\text { specified }\end{array}$ & $\begin{array}{l}\text { Dementia: CAMDEX for dementia and dementia subtypes } \\
\text { Parkinsonism: } 2 \text { of } 4 \text { cardinal signs, i.e. resting tremor, rigidity, } \\
\text { bradykinesia and impaired postural reflexes }\end{array}$ \\
\hline (4) Zaragoza & $\begin{array}{l}\text { Dementia: } 3 \text { psychiatrists blind } \\
\text { to result of screening phase I }\end{array}$ & MEC+: $71.4 \%$ & Dementia: DSM-III-R \\
\hline (5) Cantalejo & Parkinsonism: 3 neurologists & Parkinsonism: 100\% & $\begin{array}{l}\text { Parkinsonism: } 8 \text { sets; reference: progression of symptoms in the } \\
\text { past with } 2 \text { of } 4 \text { cardinal signs, i.e. resting tremor, rigidity, brady- } \\
\text { kinesia and impaired postural reflexes; Webster Scale; Hoehn and } \\
\text { Yahr index of illness severity }\end{array}$ \\
\hline (6) La Selva del Camp & Dementia: neurologist & MMSE+: $96.7 \%$ & $\begin{array}{l}\text { Dementia: scale of Blessed et al. [49]; cutoff: } \geq 4 \\
\text { For severity of dementia: DSM-III-R }\end{array}$ \\
\hline (7) Leganés & $\begin{array}{l}\text { Dementia: } 2 \text { independent } \\
\text { neurologists }\end{array}$ & Dementia: DSM-IV & \\
\hline (8) Toledo & $\begin{array}{l}\text { Dementia: } 1 \text { geriatrician or } \\
1 \text { psychiatrist (for diagnosis of } \\
\text { dementia) supported by } \\
1 \text { neurologist and } 1 \text { psychologist } \\
\text { (CAMCOG) }\end{array}$ & MEC+: $85.5 \%$ & $\begin{array}{l}\text { Dementia: CAMCOG Spanish version } \\
\text { DSM-III-R for dementia } \\
\text { NINCDS-ADRDA for Alzheimer's disease } \\
\text { NINCDS-AIREN for vascular dementia } \\
\text { CDR [50] for severity of dementia }\end{array}$ \\
\hline
\end{tabular}

CAMCOG = Cambridge Cognitive Examination; CAMDEX = Cambridge Mental Disorders of the Elderly Examination; NINCDS = National Institute of Neurological and Communicative Diseases and Stroke; ADRDA = Alzheimer's Disease and Related Disorders Association; AIREN = Association Internationale pour la Recherche et l'Enseignement en Neurosciences; CDR = Clinical Dementia Rating.

tion but sparse description of screening instruments was found in the Pamplona and Gerona parkinsonism surveys. Direct individual screening was most frequent $[1,2,5,7-12,15]$, and a relative-informant was used in all studies when direct application was not possible due to death or absence, and in 3 studies $[7,8,10]$ this was the primary systematic approach. Two surveys conducted complementary mail and telephone searches of potential cases $[8,11,12]$.

As can be seen from table 3 , the personnel responsible for phase II clinical diagnoses for dementia were psychiatrists [3] and, most frequently, neurologists $[1,2,8-11]$, who in certain instances supervised work initially done by psychologists and geriatricians [9]. For parkinsonism and stroke, diagnoses were always issued by board-certified clinical neurologists. Diagnostic criteria [22-28] and participation are also described in table 3.

We excluded the following from the core multivariate analysis for dementia: data from Toledo, since numerators, 94 dementia cases, were obtained from examining a $42 \%$ nonrandom sample of screened positive cases; data from Leganés, where only prevalence among both sexes was reported. Appropriate age groups, which varied for different entities in the core analysis, were chosen for efficient combination of part or all the reported data. Logistic regression was used for multivariate analysis of prevalence of dementia, stroke and $\mathrm{PD}$, with prevalence in Pamplona taken as reference in all cases.

Dementia, Stroke and Parkinson's Disease in Spain

\section{Results}

Prevalences selected for analysis are depicted in figure 2 for dementia, $\mathrm{AD}$ and $\mathrm{VD}$, and in figure 3 for stroke and PD. A remarkably high proportion of mild dementia versus moderate and severe dementia was evident from the data reported for Gerona. In general, the prevalence of dementia and subtypes increased with age across the sexes, but was highest in women. Insofar as stroke was concerned, when ischemic and hemorrhagic subtypes were included, prevalence increased with age and was highest in Arévalo, despite the figures proving unstable when broken down by sex. PD was most frequent in Cantalejo due to the high prevalence in men aged $80-89$ years. The remaining studies and age groups registered similar prevalence patterns.

The results of the multivariate analysis are shown in table 4. Taking Pamplona as reference, the prevalence of mild, moderate and severe dementia was significantly 


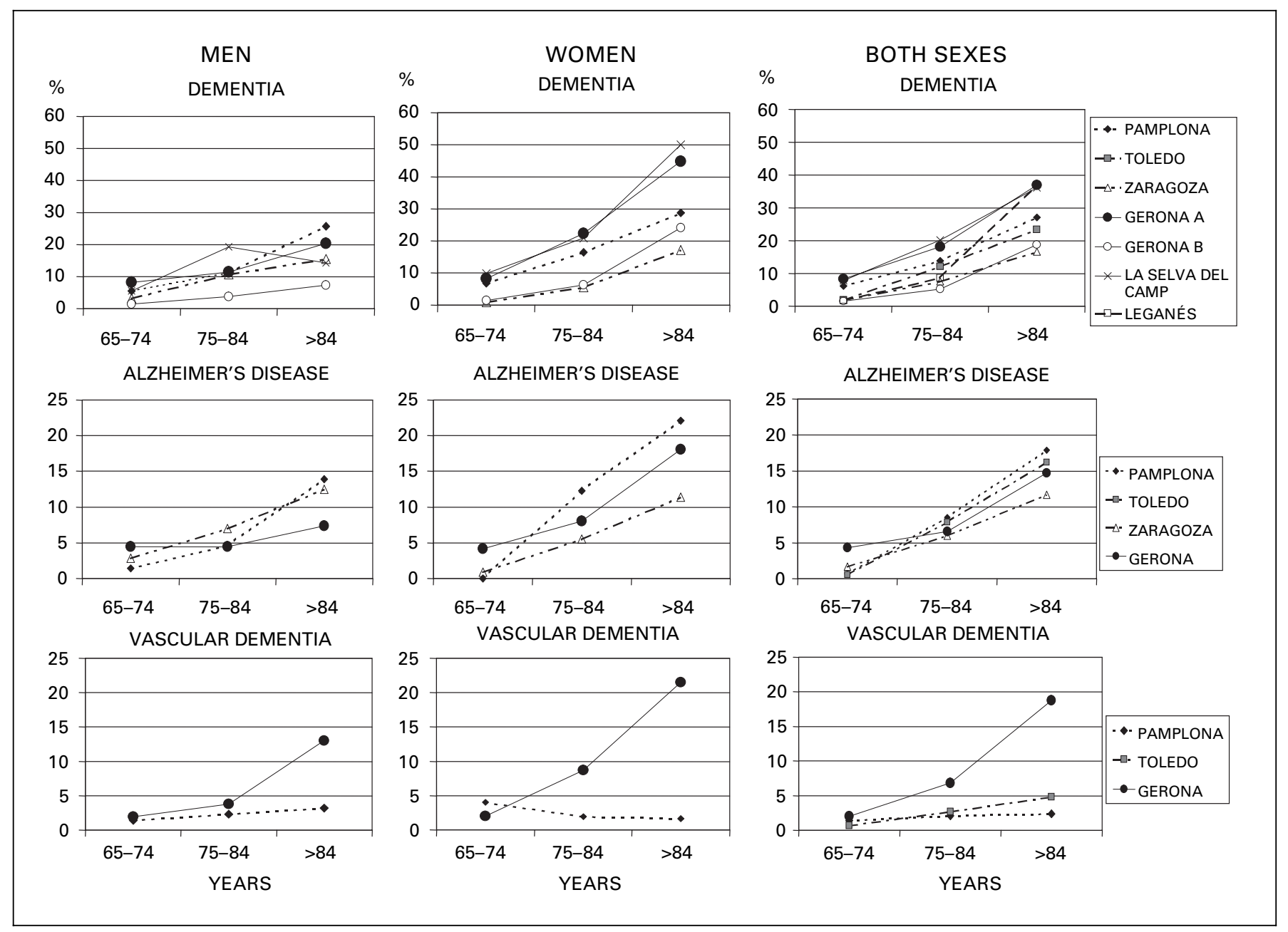

Fig. 2. Age- and sex-specific prevalence of (mild to severe) dementia, AD and VD. Gerona B: only moderate and severe dementia.

lower in Zaragoza and higher in Gerona and La Selva del Camp, albeit not significantly in the latter, with the odds ratio (OR) ranging from 49 to $138 \%$ and differences being highest among women. For AD, differences in prevalence were small, with the lowest levels, $44 \%$ of reference values, being registered for women in Zaragoza. Although based on sparse data, the most remarkable differences were for vascular dementia, particularly between Gerona and Pamplona, with a fourfold higher prevalence (OR $4.18,95 \%$ confidence interval, CI, 2.59-6.72) for both sexes, but also perceived in women and men, with OR 6.42 and $95 \%$ CI 3.23-12.3 and 2.30 and 1.10-4.79, respectively. Stroke prevalence was significantly higher in Arévalo and Gerona, especially among women in Arévalo, i.e. OR 2.10, 95\% CI 1.26-3.49. Compared to Pam- plona, the highest PD prevalence was registered for Cantalejo, resulting in an over twofold increase in both sexes (OR 2.28, 95\% CI 1.27-4.09).

Models other than those used in core analyses, which included data for dementia in both sexes in Leganés and Toledo, and data on AD and VD in Toledo, yielded agecontrolled OR similar to those shown in table 4 from core analyses for Gerona, La Selva and Zaragoza but low, statistically nonsignificant OR for dementia in Leganés $(0.86,95 \%$ CI $0.63-1.16)$ and Toledo $(0.78,95 \%$ CI 0.59 $1.01)$ and higher OR for VD in Toledo $(1.58,95 \%$ CI 0.88-2.86). When, in the same model, data for Gerona referred to prevalence of moderate and severe dementia, the OR was significantly lower, i.e. 0.43 (95\% CI 0.32 $0.57)$. 


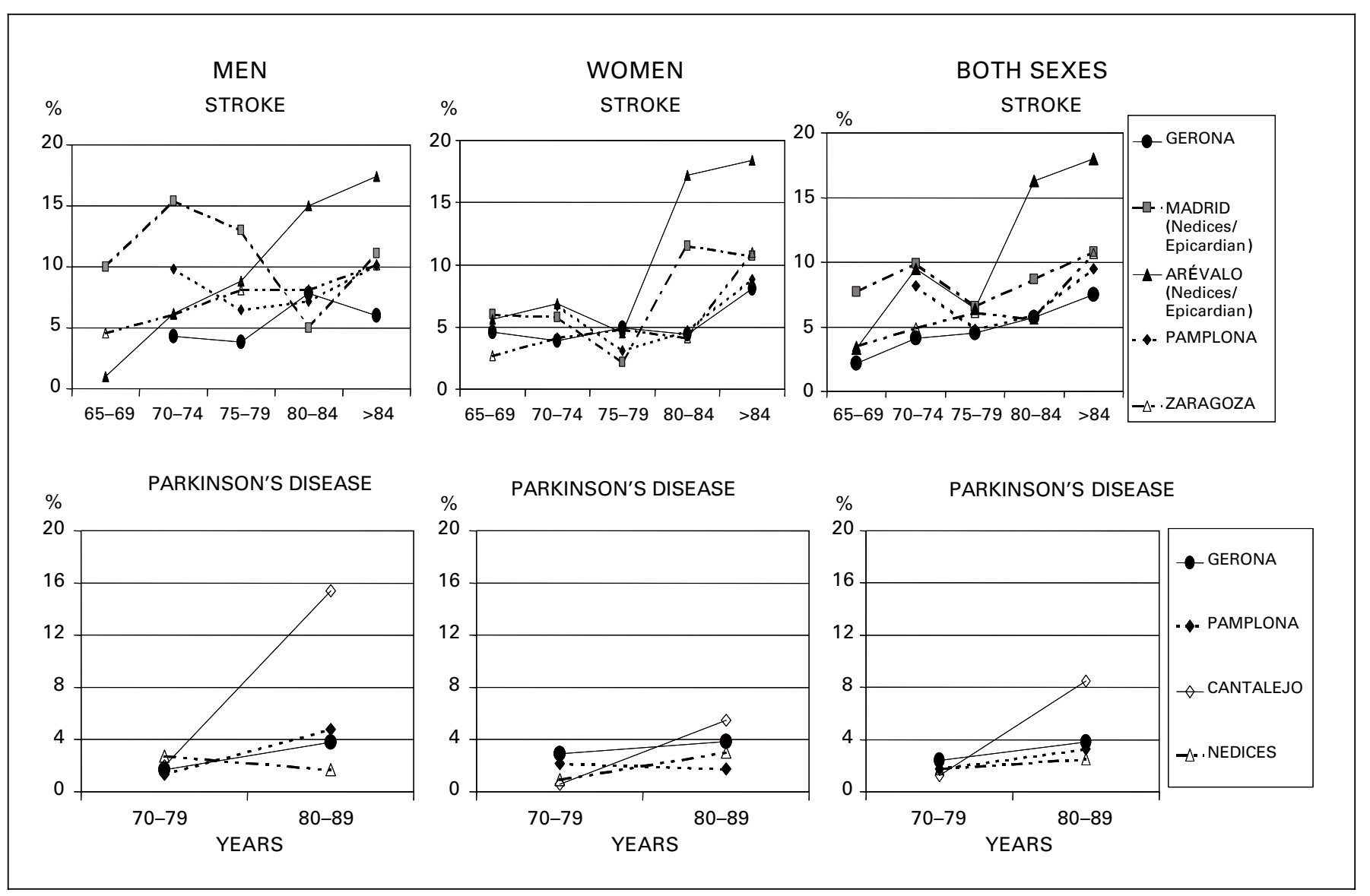

Fig. 3. Age- and sex-specific prevalence of stroke and PD.

\section{Discussion}

The results of this study reveal that there is a considerably high degree of geographical variability in Spain, both in the reported prevalence of different major neurodegenerative neurological diseases and stroke, as well as in survey research methods. The most relevant and, at times, paradoxical findings pertain to: (1) low prevalence of AD among women in Zaragoza and (2) high prevalence of VD in Gerona, stroke in Gerona and Arévalo, and PD in Cantalejo. Such variations are difficult to interpret for a number of reasons.

There were instances where the methods review revealed specific flaws, such as incomplete examination of the sample screened positive in Toledo or the residual nature of the Leganés study population. This latter population comprised 527 participants selected from 838 survivors, who were in turn drawn from among 1,283 persons interviewed in a cohort study initiated in 1993 on
1,540 persons $[8,29]$. Furthermore, the absence of a screening instrument, replaced by direct examination of the above-mentioned 527 participants by a neurologist, renders interpretation of the negative findings difficult. On occasion, methodological differences were shared by a number of studies, inasmuch as a similar combination of screening instrument, application form and diagnostic criteria were present. In such a case, comparability might be higher for specific studies and entities, e.g. MMSE with a cut-off score of $23 / 24$, participation of over $90 \%$ in phase I and over $85 \%$ in phase II, and DSM-IIIR criteria for dementia were shared by the Zaragoza and La Selva studies.

The reported sensitivity of syndrome-specific [30] or non-syndrome-specific screening instruments for parkinsonism, such as the WHO-SNES modified instrument [31], is high, namely $100 \%$, despite the latter being possibly overestimated, as revealed when an elbow rigidity test was included [32]. In addition, the incidence of PD in men has 
Table 4. OR and 95\% CI (in parentheses) controlled for age (reference: Pamplona)

\begin{tabular}{|c|c|c|c|c|c|}
\hline & Dementia & $\mathrm{AD}$ & VD & Stroke & PD \\
\hline \multicolumn{6}{|l|}{ Men } \\
\hline Pamplona & 1 & 1 & 1 & 1 & 1 \\
\hline NEDICES/EPICARDIAN (Arévalo + Madrid) & & & & & $0.80(0.44-1.47)$ \\
\hline NEDICES/EPICARDIAN (Arévalo) & & & & $1.11(0.64-1.92)$ & \\
\hline NEDICES/EPICARDIAN (Madrid) & & & & $0.64(0.39-1.07)$ & \\
\hline Gerona & $1.02(0.71-1.49)$ & $0.97(0.57-1,66)$ & $2.30(1.10-4.79)$ & $1.82(0.98-3.37)$ & $0.77(0.36-1.63)$ \\
\hline Zaragoza & $0.71(0.45-1.13)$ & $1.09(0.61-1.96)$ & & $1.04(0.72-1.50)$ & \\
\hline Cantalejo & & & & & $2.23(1.02-4.86)$ \\
\hline La Selva del Camp & $1.14(0.68-1.90)$ & & & & \\
\hline \multicolumn{6}{|l|}{ Women } \\
\hline Pamplona & 1 & 1 & 1 & 1 & 1 \\
\hline NEDICES/EPICARDIAN (Arévalo + Madrid) & & & & & $1.04(0.51-2.12)$ \\
\hline NEDICES/EPICARDIAN (Arévalo) & & & & $2.10(1.26-3.49)$ & \\
\hline NEDICES/EPICARDIAN (Madrid) & & & & $1.05(0.65-1.70)$ & \\
\hline Gerona & $1.44(1.10-1.91)$ & $0.81(0.56-1.15)$ & $6.42(3.23-12.73)$ & $1.45(0.74-2.85)$ & $1.88(0.89-3.97)$ \\
\hline Zaragoza & $0.36(0.23-0.55)$ & $0.44(0.27-0.72)$ & & $1.10(0.74-1.65)$ & \\
\hline Cantalejo & & & & & $2.34(0.95-5.72)$ \\
\hline La Selva del Camp & $1.47(0.98-2.22)$ & & & & \\
\hline \multicolumn{6}{|l|}{ Both sexes } \\
\hline Pamplona & 1 & 1 & 1 & 1 & 1 \\
\hline NEDICES/EPICARDIAN (Arévalo + Madrid) & & & & & $0.90(0.57-1.42)$ \\
\hline NEDICES/EPICARDIAN (Arévalo) & & & & $1.58(1.09-2.28)$ & \\
\hline NEDICES/EPICARDIAN (Madrid) & & & & $0.84(0.60-1.19)$ & \\
\hline Gerona & $1.30(1.04-1.62)$ & $0.87(0.65-1.17)$ & $4.18(2.59-6.72)$ & $1.64(1.04-2.58)$ & $1.25(0.75-2.08)$ \\
\hline Zaragoza & $0.48(0.35-0.66)$ & $0.63(0.43-0.91)$ & & $1.06(0.81-1.39)$ & \\
\hline Cantalejo & & & & & $2.28(1.27-4.09)$ \\
\hline La Selva del Camp & $1.33(0.97-1.84)$ & & & & \\
\hline
\end{tabular}

A Stata 8.0 package was used to fit a logistic fixed effect model with 3 independent, dummy variables, survey, sex and age as described in figures 2 and 3.

recently been reported to be double that of women [11,33]. These two elements are consistent with the high PD prevalence found in Cantalejo as a result of the extraordinary case-finding effort made in the survey. This would in turn suggest that PD prevalence observed in Pamplona and Gerona, as well as that observed in other European populations [4], might constitute undercounts and a higher-thanreported proportion of $\mathrm{PD}$ underdiagnosis.

The considerable variation in stroke prevalence between surveys might be difficult to attribute to methodology, despite the low level of collaboration registered in the NEDICES Lista and Margaritas subpopulations, an aspect particularly stressed by the authors [34] since it reached $77 \%$ for elderly women. The high stroke prevalence in Arévalo and Gerona is difficult to explain, though in the case of the Arévalo women it may conceivably be related to rural environment. The modest differences in prevalence of stroke between Gerona and Pamplona, with OR 1.64, might, if mainly due to a variation in stroke incidence, be consistent with small differences in VD prevalence, a feature not fully observed in our study.
The large variation of prevalence of VD might constitute this review's most important finding and may explain the variation in prevalence of dementia when data for both entities are available. Since (1) the proportion of prevalent dementia diagnosed before the survey is infrequently reported but nevertheless low, e.g. 30\% in Leganés [8], (2) there is a considerably high degree of variation in participation during screening (range 82-95\%) [3, 9] or thereafter (range 71-100\%) [5, 9], in the choice of screening instrument, with an ensuing wide margin for differential sensitivity, and in diagnostic criteria, (3) there are important limitations on assigning an etiological diagnosis to 'probable dementia', 44\% in the Gerona survey, and (4) concordance in AD diagnosis is modest, with a range for $\kappa$ of $0.51-0.73$ in the best-quality studies [35], it might be reasonable for reported differences in prevalence of dementia or etiological subtypes to be attributed to differences in clinical diagnostic methodology or traditions among specialists. The opposite pattern of dementia distribution by AD and VD subtypes seen in 3 surveys, Zaragoza, Pamplona and Gerona, namely AD 78, 61 and 
$41 \%$ versus VD 11.9 [3], 13 and 38\%, may suggest that methods, more restrictive diagnosis of VD diagnosis in Zaragoza and, to a lesser extent, geographical variability in vascular risk factors for dementia, as reflected in the higher frequency of stroke in Gerona (fig. 3), explain the major features of reported dementia prevalence in Spain.

Comparison with international data is not a designated aim of this study. However, the stroke prevalence in Zaragoza was found to be similar to that reported in Rotterdam, Stockholm and the multicenter Italian Longitudinal Study on Aging [6], and the proportion of VD in Zaragoza was found to be low compared to that in Pamplona and other European studies [5].

During the last decade, stroke mortality in the northern half of Spain has been similar to and that in the southern half higher than comparable rates for West European populations [36]. This review suffers from a lack of surveys for southern Spain. The geographical stroke mortality pattern would suggest that in southern Spain frequencies of stroke, VD and dementia in general could be assumed to be higher than those described in available reports. Arterial hypertension, a well-known risk factor for stroke which is insufficiently controlled in Spain [37], may also constitute a risk factor for $\mathrm{AD}$ and dementia [38, $39]$ as the relationship between stroke, vascular risk fac- tors and AD is quite complex [40]. These facts suggest that the simultaneous study of dementia, stroke and vascular risk factors in Spain, particularly in the south, is crucial for an appropriate etiological diagnosis to be made and preventive measures implemented. Lack of PD diagnosis might be corrected by primary-care facility interventions targeted at selected groups [41].

In brief, despite scant information and methodological heterogeneity, the prevalence of stroke and dementia in Spain may vary geographically. Reported figures for prevalence of PD, dementia and stroke should be cautiously assigned to regional or national Spanish populations, due to the small study size and specific nature of the populations surveyed. Coordinated, harmonized and geographically targeted surveys are called for.

\section{Acknowledgements}

The authors would like to thank Javier Almazán for his support with data analysis and design of graphs, and Margarita Ramírez for her bibliographic work. We should also like to thank Pablo Martínez for his invaluable criticism and suggestions. Financial support was obtained from the Pfizer Foundation and Spanish Neurological Disorders Research Network (Red Temática de Centros de Investigación en Enfermedades Neurológicas).

\section{References}

$>1$ Manubens JM, Martínez-Lage JM, Lacruz F, Muruzabal J, Larumbe R, Guarch C, et al: Prevalence of Alzheimer's disease and other dementing disorders in Pamplona, Spain. Neuroepidemiology 1995;14:155-164.

-2 Vilalta-Franch J, López-Pousa S, Llinás-Reglá $\mathrm{J}$ : Prevalencia de demencias en una zona rural. Estudio de Girona. Rev Neurol 2000;30:10261032.

3 Lobo A, Saz P, Marcos G, Día JL, de la Cámara $C$ : The prevalence of dementia and depression in the elderly community in a southern European population: The Zaragoza Study. Arch Gen Psychiatry 1995;52:497-506.

$\checkmark 4$ Rijk MC, Tzourio C, Breteler MMB, et al: Prevalence of parkinsonism and Parkinson's disease in Europe: The EUROPARKINSON Collaborative Study. J Neurol Neurosurg Psychiatry 1997;62:10-15.

5 Lobo A, Launer LJ, Fratiglioni L, Andersen K, Di Carlo A, Breteler MMB, et al: Prevalence of dementia and major subtypes in Europe: A collaborative study of population-based cohorts. Neurologic Diseases in the Elderly Research Group. Neurology 2000;54(suppl 5):S4-S9.
6 Di Carlo A, Launer LJ, Breteler MM, Fratiglioni MD, Lobo A, Martínez-Lage J, et al: Frequency of stroke in Europe: A collaborative study of population-based cohorts. ILSA Working Group and the Neurologic Diseases in the Elderly Research Group. Neurology 2000; 54(suppl 5):S28-S33.

7 Clavería LE, Duarte J, Sevillano MD, PérezSempere A, Cabezas C, Rodríguez F, et al: Prevalence of Parkinson's disease in Cantalejo, Spain: A door-to-door survey. Mov Disord 2002; 17:242-249.

$\checkmark 8$ Zunzunegui MV, del Ser T, Rodríguez-Laso A, García de Yébenes MJ, Domingo J, Otero A: Demencia no detectada y utilización de los servicios sanitarios: implicaciones para la atención primaria. Aten Primaria 2003;31:581586.

9 García FJ, Sánchez MA, Pérez A, Martín E, Marsal C, Rodríguez G, et al: Prevalencia de demencia y de sus subtipos principales en sujetos mayores de 65 años: efecto de la educación y ocupación. Estudio Toledo. Med Clin (Barc) 2001;116:401-407.

10 Pi J, Olivé JM, Roca J, Masana Ll: Prevalence of dementia in a semi-rural population of Catalunya, Spain. Neuroepidemiology 1996;15:3341.
Benito-León J, Bermejo-Pareja F, Rodríguez J, Molina JA, Gabriel R, Morales JM: Prevalence of $\mathrm{PD}$ and other types of parkinsonism in three elderly populations of central Spain. Mov Disord 2003;18:267-274.

12 Bermejo-Pareja F, Vega S, Morales J, Díaz J, López L, Parra D, et al: Prevalence of stroke in two samples (rural and urban) of old people in Spain: A pilot door-to-door study carried out by health professionals. Neurología 1997;12: 157-161.

13 Gabriel R, Alonso M, Bermejo-Pareja F, Muñiz J, López I, Suárez C, et al, and Cooperative Group EPICARDIAN: Proyecto EPICARDIAN: estudio epidemiológico sobre enfermedades y factores de riesgo cardiovasculares en ancianos españoles. Diseño, métodos y resultados preliminares. Rev Esp Geriatr Gerontol 1996;31:327-334.

14 Gabriel R, Bermejo-Pareja F, Vega S, Muñiz J, López I, Suárez C, et al: Survey of cardiovascular diseases (acute myocardial infarction and stroke) and their risk factors in the elderly population of Spain: The EPICARDIAN study Methods and demographic findings. CVD Prevent 1999;2:290-300. 
15 López-Pousa S, Vilalta J, Llinás J: Prevalencia de la enfermedad vascular cerebral en España: estudio en un área rural de Girona. Rev Neurol (Barc) 1995;23:1081-1086.

16 Rijk MC, Launer LJ, Berger K, Breteler MMB, Dartigues JF, Baldereschi M, et al, for the Neurologic Diseases in the Elderly Research Group: Prevalence of Parkinson's disease in Europe: A collaborative study of populationbased cohorts. Neurology 2000;54(suppl 5): S21-S23.

17 Acosta-Varo J, de Pedro-Cuesta J: Prevalence survey of movement disorders, epilepsy, hypertension and smoking habit in Vejer de la Frontera, southern Spain. I. Methodology. Parkinsonism Relat Disord 1996;2:195-203.

18 Matías-Guiu J, Viñets C, Falip R, LópezArlandis J, Oltra A, Canet T, et al: Epidemiología descriptiva del accidente isquémico transitorio: estudio en Muro d'Alcoi. Rev Neurol (Barc) 1995;23:422-424.

$\checkmark 19$ Bergareche A, de la Puente E, López de Munain A, Sarasqueta C, de Arce A, Poza JJ, et al: Prevalence of essential tremor: A door-to-door survey in Bidasoa, Spain. Neuroepidemiology 2001;20:125-128.

-20 Folstein MF, Folstein SE, McHugh PR: 'Minimental state': A practical methd for grading the cognitive state of patients for the clinician. J Psychiatr Res 1975;12:189-198.

21 Escribano MV, Pérez-Dively M, García FJ, Pérez A, Romero L, Ferrer G: Validación del MMSE de Folstein en una población española de bajo nivel educativo. Rev Esp Geriatr Gerontol 1999;34:319-326.

-22 Lobo A, Ezquerra J, Gómez F, Sala JM, Seva A: El 'Mini Examen Cognoscitivo': un test sencillo, práctico, para detectar alteraciones intelectivas en pacientes médicos. Actas Luso Esp Neurol Psiquiatr Cienc Afines 1979;3:189202.

$\checkmark 23$ Roth M, Tym E, Mountjoy CQ, Huppert FA, Hendrie H, Verma S, et al: CAMDEX: A standardized instrument for the diagnosis of mental disorders in the elderly with special reference to the detection of dementia. Br J Psychiatry 1986;149:698-709.

24 Vilalta J, Llinás S, López-Pousa S, Amiel J, Vidal C: CAMDEX: Validación de la adaptación española. Neurología 1990;5:117-120.

25 American Psychiatric Association: Diagnostic and Statistical Manual of Mental Disorders. Washington, American Psychiatric Association, 1987.

-26 McKhann G, Drachman D, Folstein M, Katzman R, Price D, Stadla EM: Clinical diagnosis of Alzheimer's disease: Report of the NINCDSADRDA work group under the auspices of the Department of Health and Human Services Task Force on Alzheimer's disease. Neurology 1984;34:939-944.
27 Román GC, Tatemichi TK, Erkinjuntti T, Cummings JL, Medeu JC, García JH, et al: Vascular dementia: Diagnostic criteria for research studies. Report of the NINCDS-AIREN International Workshop. Neurology 1993;43: 250-261.

28 Hachinski VC, Lliff LD, Zihnka E, Duboulay GH, McAllister VL, Marshall J, et al: Cerebral blood flow in dementia. Arch Neurol 1975;32: 632-637.

29 Zunzunegui MV, Béland F, Gutiérrez-Cuadra P: Loss to follow-up in a longitudinal study on aging in Spain. J Clin Epidemiol 2001;54:501510

30 Duarte J, Clavería LE, de Pedro-Cuesta J, Sempere AP, Coria F, Calne DB: Screening Parkinson's disease: A validated questionnaire of high specificity and sensitivity. Mov Disord 1995; 11:643-649.

31 Meneghini F, Rocca WA, Anderson DW, Grigoletto F, Morgante L, Regio A, Savettieri G, et al: Validating screening instruments for neuroepidemiologic surveys: Experience in Sicily. Sicilian Neuro-Epidemiologic Study (SNES) Group. J Clin Epidemiol 1992;45:319-331.

-32 Morgante L, Rocca WA, Di Rosa AE, de Domenico P, Grigoletto F, Meneghini F, et al: Prevalence of Parkinson's disease and other types of parkinsonism: A door-to-door survey in three Sicilian municipalities. The Sicilian Neuro-Epidemiologic Study (SNES) Group. Neurology 1992;42:1901-1907.

33 Maggi S, Zuchetto M, Grigoletto F, Baldereschi M, Candelise L, Scarpini E, et al: The Italian Longitudinal Study on Aging (ILSA): Design and methods. Aging (Milano) 1994;6:464473.

34 Bermejo-Pareja F, Gabriel R, Vega S, Morales JM, Rocca WA, Anderson DW: Problems and issues with door-to-door, two-phase surveys: An illustration from central Spain. Neuroepidemiology 2001;20:225-231.

35 Knopman DS, DeKosky ST, Cummings JL, Chui H, Corey-Bloom J, Relkin N, et al: Practice parameter: Diagnosis of dementia (an evidence-based review). Report of the Quality Standards Subcommittee of the American Academy of Neurology. Neurology 2001;56: 1143-1153.

-36 Olalla MT, Medrano MJ, Sierra MJ, Almazán J: Mortalidad por enfermedad cerebrovascular en España. Rev Neurol 1999;29:872-878.

37 Banegas JR, Rodríguez-Artalejo F, Ruilope LM, Graciani A, Luque M, de la Cruz-Troca $\mathrm{JJ}$, et al: Hypertension magnitude and management in the elderly population of Spain. $\mathrm{J}$ Hypertens 2002;20:2157-2184.
8 Skoog I, Gustafson D: Hypertension, hypertension-clustering factors and Alzheimer's disease. Neurol Res 2003;25:675-680.

39 in't Veld BA, Ruitenberg A, Hofman A, Stricker BH, Breteler MM: Antihypertensive drugs and incidence of dementia: The Rotterdam Study. Neurobiol Aging 2001;22:407-412.

40 Honig LS, Tang MX, Albert S, Costa R, Luchsinger J, Manly J, et al: Stroke and the risk of Alzheimer disease. Arch Neurol 2003;60: 1707-1712.

41 Sevillano-García MD, Cuadrado-Gamarra JL, de Pedro-Cuesta J: Enfermedad de Parkinson en España: evidencias de infradiagnóstico y puntos de partida para su reducción. Rev Neurol 1999;29:881-883.

42 WHO Monica Project: Monica Manual. Cardiovascular Diseases Unit. Geneva, WHO, 1990.

43 O'Mahony PG, Dobson R, Rodgers H, Oliver OFW, Thomson RG: Validation of a population screening questionnaire to assess prevalence of stroke. Stroke 1996;26:1334-1337.

44 Copeland JRM, Kelleher MJ, Kellett JM, Gourlay J, Gurland BJ, Fleiss JL, Sharpe L: A semi-structured clinical interview for the assessment of diagnosis and mental state in the elderly: the Geriatric Mental State Schedule. I. Development and reliability. Psychol Med 1976;6:439-449.

45 Dewey ME, Copeland JRM: Computerised psychiatric diagnosis in the elderly: AGECAT. J Microcomput Appl 1986;9:135-140.

46 Pfeiffer E: A short portable mental status questionnaire for the assessment of organic brain deficit in elderly patients. J Am Geriatr Soc 1975;23:433-441.

47 Solomon PR, Hirschoff A, Kelly B, Relin M, Brush M, DeVeaux RD, Pendlebury WW: A 7 minute neurocognitive screening battery highly sensitive to Alzheimer's disease. Arch Neurol 1998;55:349-355.

48 Morales JM, González-Montalvo JI, Bermejo F, Del Ser T: The screening of mild dementia with a shortened Spanish version of 'Informant Questionnaire on Cognitive Decline in the Elderly'. Alzheimer Dis Assoc Disord 1995;9: 105-111.

49 Blessed G, Tomlinson BE, Roth M: The association between qualitative measures of dementia and of senile change in the cerebral grey matter of elderly subjects. Br J Psychiatry 1968;114:797-811.

50 Hughes C, Berg L, Danzinger WI, Coben LA, Martin LR: A new clinical scale for the staging of dementia. Br J Psychiatry 1982;140:566572 . 